\author{
Marcin BEDNAREK ${ }^{1}$, Tadeusz DĄBROWSKI ${ }^{2}$ \\ ${ }^{1}$ Rzeszow University of Technology (Politechnika Rzeszowska) \\ ${ }^{2}$ Military University of Technology (Wojskowa Akademia Techniczna)
}

\title{
SELECTED TOOLS INCREASING HUMAN RELIABILITY IN THE ANTROPOTECHNICAL SYSTEM
}

\section{Wybrane narzędzia zwiększające niezawodność człowieka w systemie antropotechnicznym}

\begin{abstract}
Distributed control systems (DCS) consist of process stations, operator stations, engineering stations and other elements, which all enable the exchange of data between industrial systems. Process stations are industrial controllers. They manage process control. Operator stations are used for visualisation and operator interactions. Engineering stations are designed for configuration, programming and executing control and visualisation software. Elements of the DCS system are connected by an industrial network. DCS must be properly designed, commissioned, used and operated. There is a human factor in each of these phases of the system's existence. The article discusses software tools that increase human reliability in such a system, made in the visualisation package, i.e. the graphic environment used to visualize the process at the operator's station.
\end{abstract}

Keywords: social engineering system, distributed control system, operator reliability

Streszczenie: Rozproszone systemy sterowania (DCS) składaja się ze stacji procesowych, stacji operatorskich, stacji inżynierskich oraz pozostatych elementów pozwalajacych na wymiane danych pomiędzy systemami przemystowymi. Stacje procesowe sa sterownikami przemysłowymi prowadzacymi sterowanie procesami, stacje operatorskie słuza do wizualizacji i oddziaływań operatorskich, stacje inżynierskie przeznaczone sa do konfiguracji, programowania i uruchamiania programów sterowania oraz wizualizacji. Elementy systemu DCS połaczone sa za pomoca sieci przemysłowej. DCS należy odpowiednio zaprojektować, uruchomić oraz użytkować $i$ obstugiwać. W każdej z tych faz istnienia systemu mamy do czynienia z czynnikiem ludzkim. W artykule omówiono narzędzia software’owe zwiększające niezawodność człowieka $w$ takim układzie, wykonane $w$ pakiecie wizualizacji, czyli środowisku graficznym wykorzystywanym do wizualizacji procesu na stacji operatorskiej.

Słowa kluczowe: system socjotechniczny, rozproszony system sterowania, niezawodność operatora 


\section{Introduction}

Distributed Control Systems consist of process stations, operator stations, engineering stations and other elements, which all enable the exchange of data between industrial systems [3, 12]. Process stations are industrial controllers, which control processes, operator stations are used for visualisation and operator interactions, and engineering stations are designed for configuration, programming and executing control and visualisation software. DCS elements are interconnected via an industrial network.

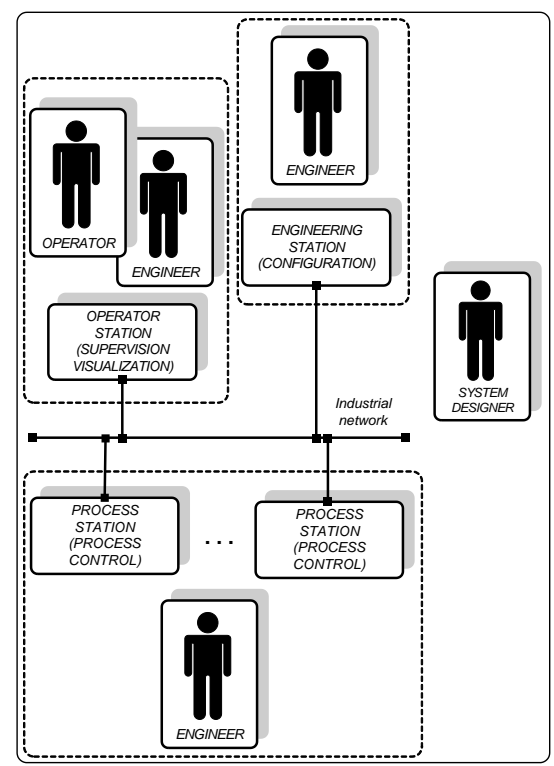

Fig. 1. Considered distributed control system

The abovementioned system can be treated as anthropotechnical (alternatively as sociotechnical) [8]. The human factor impacts each of the significant stages of system existence. Various roles of a human can be distinguished (fig. 1):

- system designer - reliable system operation, selection of hardware elements, the configuration of data exchange between industrial network stations,

- engineer - system commissioning, the software configuration of process stations, operator station configuration - synoptic images, virtual control stations (from engineering station level),

- operator - visualisation observations, correct system operation (from operator station level).

The reliability of such a system depends on the reliability of the technical segment (hardware and software), but also the reliability of operator, engineer and designer actions.

Human reliability is significantly impacted by the level of his/her knowledge and psychomotor predisposition [4-6, 8]. Improving the reliability of an engineer/ designer/ 
operator can be achieved by, among others, appropriate learning and knowledge (cognition) verification. Figure 2 shows a diagram of the impact of utilising tools supporting the reliability-related properties of a system through improving human reliability within an anthropotechnical system. As can be seen, the tools described in the further section of the research paper impact most of the system elements.

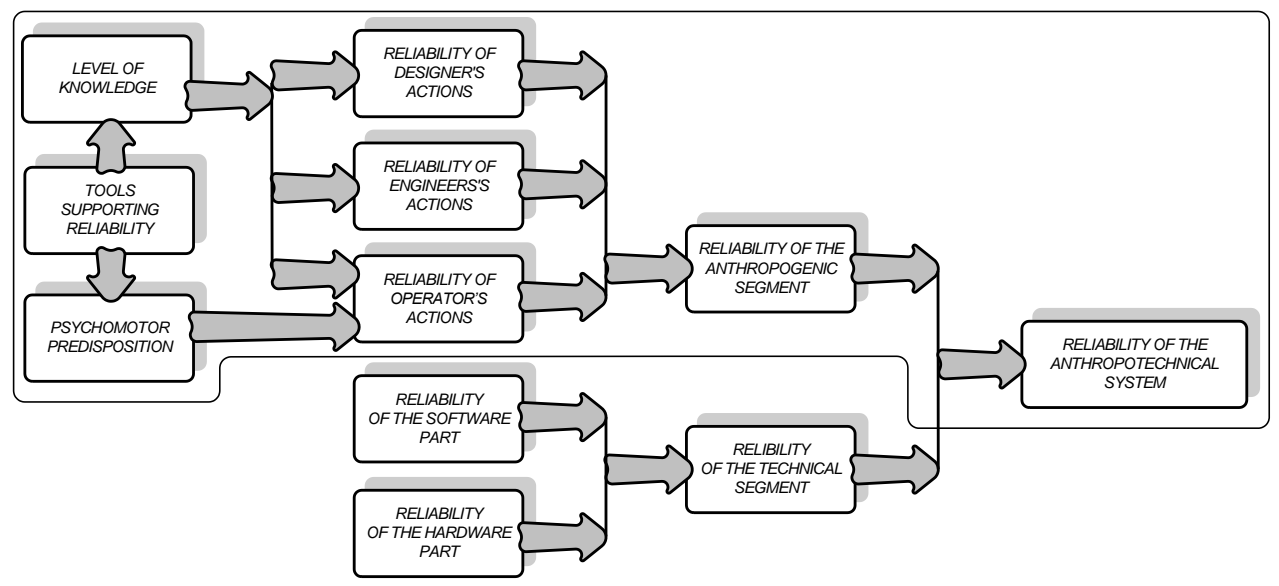

Fig. 2. Demonstration of the impact of tools supporting the reliability properties of an anthropotechnical system

\section{Role and place of tools supporting human reliability}

There are numerous ways to gain technical knowledge. An engineer, designer and operator of a distributed control system, in order to improve his/her knowledge, can use, among others:

- technical documentation contained in static text files, equivalent to paper, printed OMM documentation or technical bulletins issued by equipment manufacturers and integrators [14];

- interactive help included directly in the operated IT system, frequently enhanced with a context menu, which facilitates searching for the required terms [16];

- technical documentation containing embedded multimedia files, which enable a replay of a training video, after becoming familiar with the theoretical section of the elaboration, is used in order to increase the knowledge level of an operator handling the system;

- web portal supporting products, which contains themed and chronologically arranged educational materials [15]; 
- web corporate platform made available to the customers based on log-ins, which apart from standard installation elements of the system, often contains additional documents [11];

- multimedia presentations available from the level of a subscribed internet service, which enables a video exchange [13].

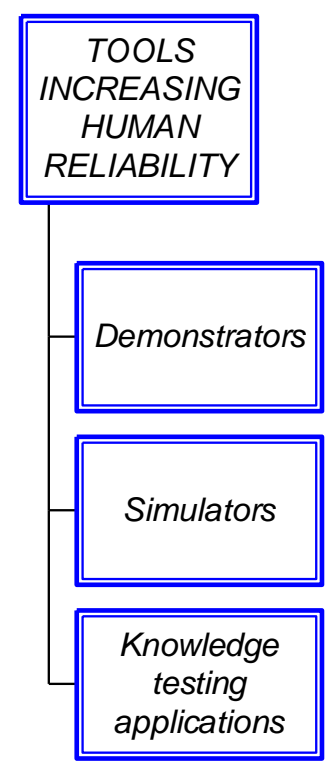

Fig. 3. Categories of developed tools improving human reliability

Improving the reliability of an anthropogenic factor within a distributed control system (treated as an anthropotechnical system) can be achieved through the use of supporting IT tools discussed in the article. Figure 3 shows the categories of tools, which include developed software (fig. 4):

- interactive computer demonstrators, which enable both the comparison of the actions of certain mechanisms, as well as the development of an independent example based on user data (cf. checksum calculation demonstrator - section 3 of the article);

- simulators, which enable configuration of a certain fragment of a system or, e.g. a link, and testing the practical skills of an operator [11] (cf. industrial radio-modem console system simulator - section 4);

- knowledge testing applications (often in the form of a "quiz"), which are used to verify user knowledge; developed in the form of stand-alone applications or within e-learning systems [9] (cf. application for testing operator knowledge - section 5 of the article); 


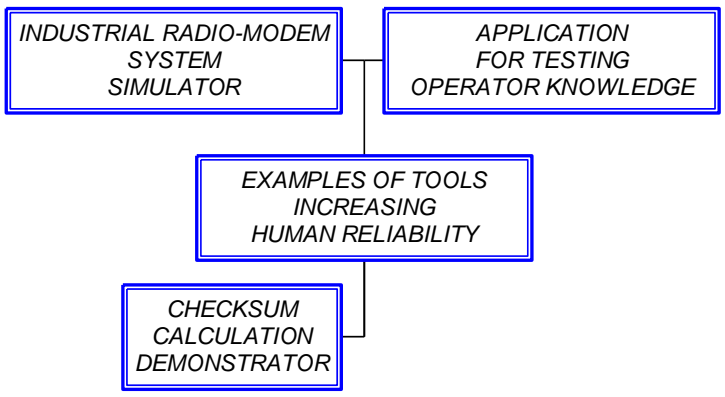

Fig. 4. Examples of tools supporting human reliability

The applications for improving human reliability within an anthropotechnical system, i.e.:

- checksum calculation demonstrator,

- industrial radio-modem console system simulator,

- application for testing the operator's knowledge,

have been developed within a visualisation package [12]. This is an important aspect of novelty. SCADA (Supervisory Control and Data Acquisition) Intouch, which is used by the designer, engineer, as well as operator, provides additional possibilities for the practical training of its operation. There is no need to additionally make the user familiar with the "mysteries" of operating foreign apps.

\section{Checksum calculation demonstrator}

This application enables all user groups to analyse the principle of calculating the cyclic CRC16 checksum [18]. 


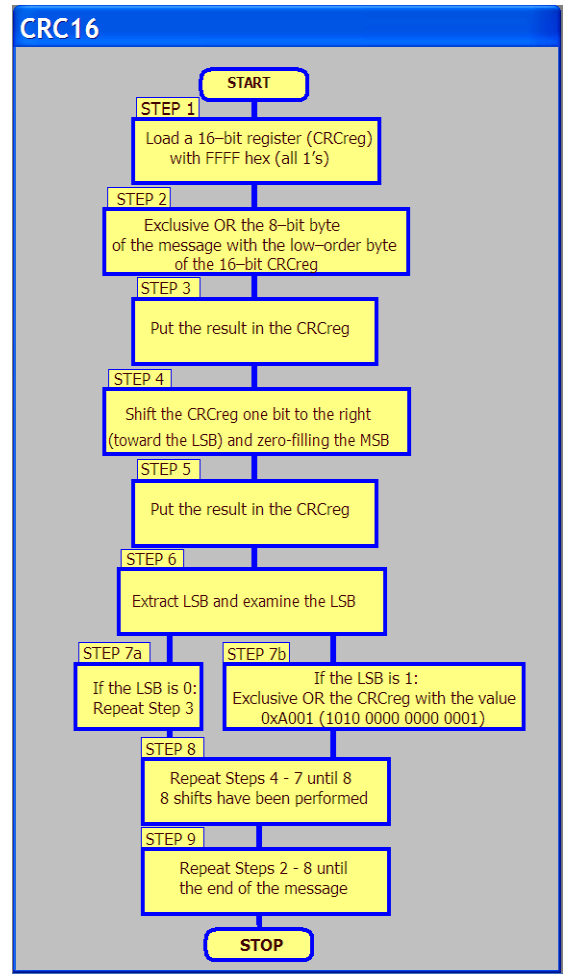

Fig. 5. CRC16 checksum calculation demonstrator

Checksum calculations are used, among others, in the data transmission process within distributed control systems, for verifying the integrity of the sent message. Comparing the value of a checksum calculated based on significant data of a received message with a value attached to it is a crucial activity prior to a potential attempt at retransmitting the message. The application of transmission integrity protection is necessary for all control systems. The developed demonstrator app enables:

- Automatic visualisation of the checksum calculation process principle. The demonstrator automatically reconstructs the sequence of calculation stages. The screen displays subsequent calculation process stages, using a different colour to highlight the block frames of an algorithm displayed on the synoptic screen (fig. 5).

- Automatic visualisation of a checksum calculation example. Just like in the case of the automatic visualisation of the process principle, this operation is automatic. It is supplemented by pop-up windows with partial and end values of the checksum register.

- The "step by step" observation of the calculation principle for each of the checksum determination stages, initiated by an operator. There is an additional option to obtain supplemental information, after clicking the side of a visualised algorithm. 
- Being used as a quasi-calculator for calculating the checksum of a set character string (entered value of a 16bit user word).

\section{Industrial radio-modem console system simulator}

Actual industrial radio-modems [2,7] enable the user to set up radio communication between DCS elements. Proper configuration of actual devices leads to the formation of a data transmission line, which is practically "invisible" to the inter-communicating pieces of equipment. Although there are graphical modem configurators [1, 12], they do not have the function to autonomously simulate a set-up transmission channel, which enables the user to obtain the effect of link set-up without using the actual equipment. This allows for the configuration of an actual radio-modem system and for sending configuration settings to the devices.

Owing to the use of a radio-modem console system application, developed within a visualisation package, a user has the opportunity to set-up a simulated radio link [5] without the need to use hardware. In order to do so:

1. Complete preliminary configuration, which involves using appropriate check-boxes to select an option of inter-communication between individual modems (fig. 6). The next step after ticking a check-box result involves the need to configure all modems participating in simulated communication (ticked).

2. Configure transmission parameters for each simulated modem (frequency, transmission channel, outgoing and incoming data address, as well as the remaining settings). These activities are performed in several available ways, just like for an actual system, that is, via a simulated terminal operation window; - a series of questions and answers or through using virtual "up", "down", "cancel" and "confirm" buttons, and an alphanumerical display, similar to an actual one located on the casing of a radio-modem, which displays messages.

3. Switch (by clicking a relevant button) to the view of a set-up connection (fig. 7). Lines with arrows showing the direction and return of sent data will appear in the event of correctly configuring a series of modems.

A connection set-up in an aforementioned manner enables the user to open a window with the simulated terminal and test communication through entering custom keyboard characters in the text box assigned to the extreme transmitting modem and observing the characters appearing in the window with the receiving modem terminal on the other side of the set-up connection. Proper configuration of a modem chain also enables the user to set up a radio-modem console system simulator connection through emulated serial ports with external slave applications operating as per the Modbus protocol. 


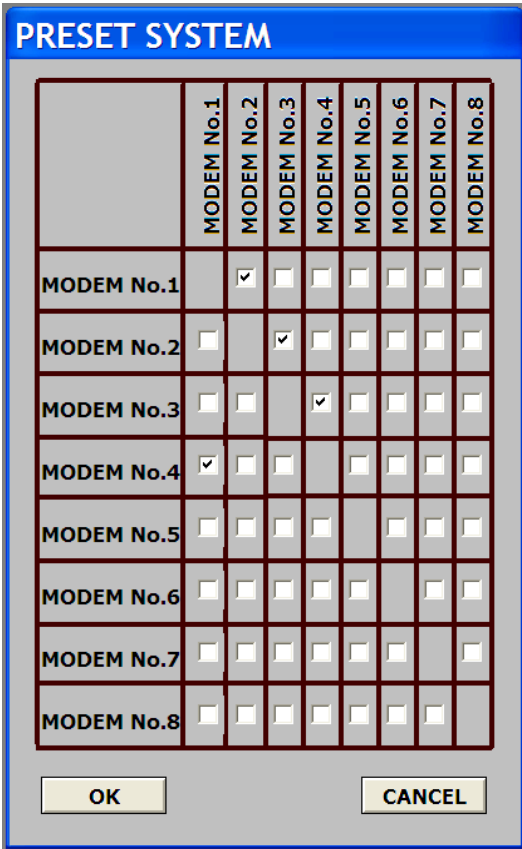

Fig. 6. Industrial radio-modem assembly simulator - preliminary configuration

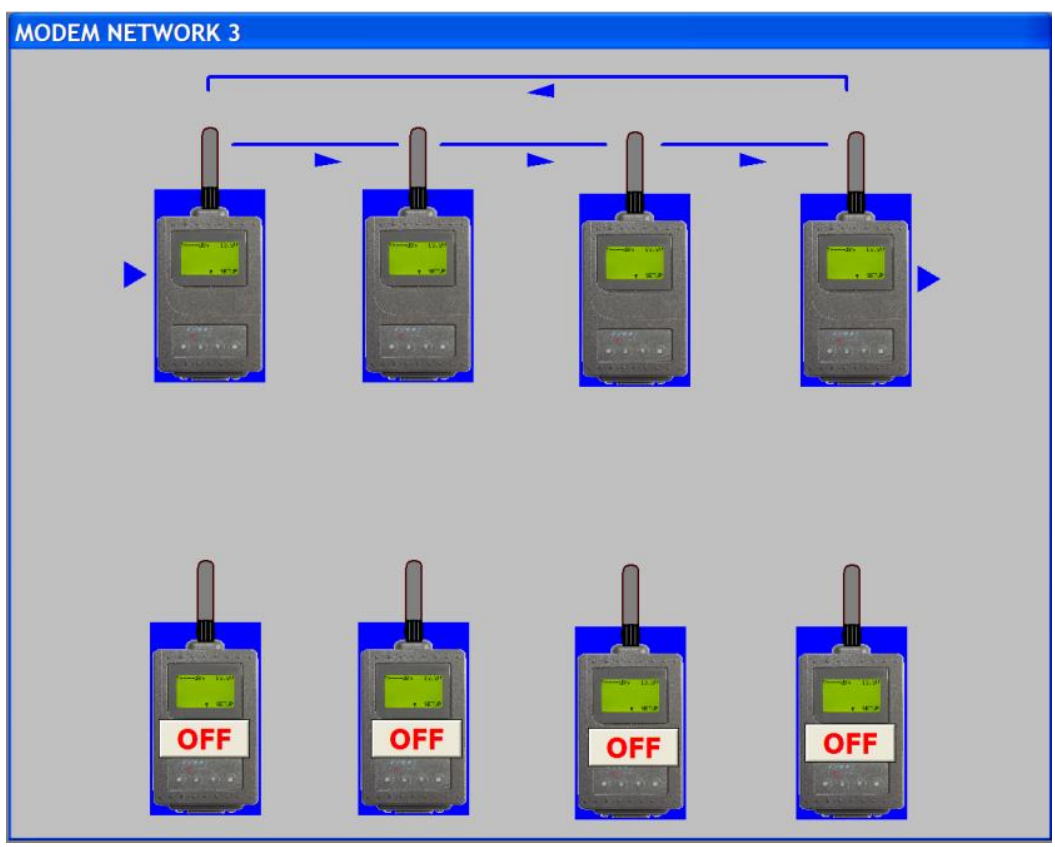

Fig. 7. Industrial radio-modem assembly simulator - system active 


\section{Application for testing operator knowledge}

The last of the tools referred to in section 2, which improve the reliability of a human within the considered anthropotechnical system is an application for testing operator knowledge [5]. Once again, it should be emphasised that it has been developed in a graphical environment of the SCADA system, which is used by an operator in everyday work. It enables a single- or multi-station operation.

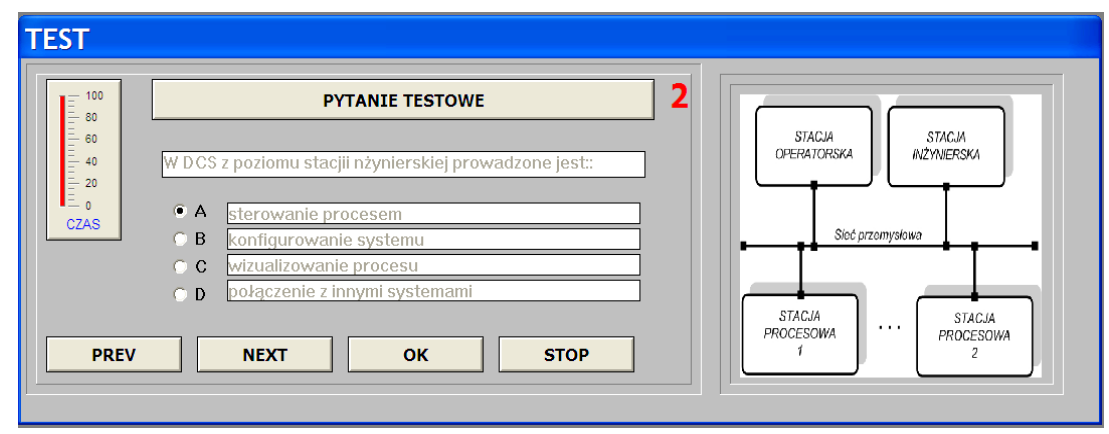

Fig. 8. Application for testing operator knowledge - quiz window

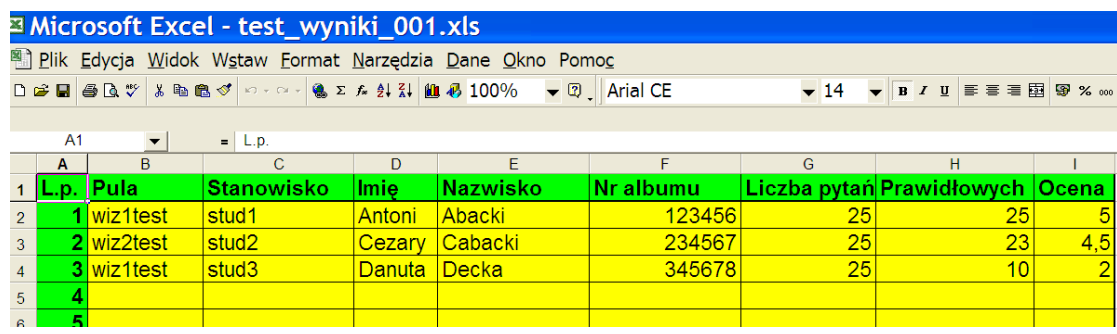

Fig. 9. Application for testing operator knowledge - results

The application can be used as follows:

1. Preliminary app configuration involving a master station setting, among others, the number of stations participating in the test, user data and IDs, number of test questions, activity time, source location and question file.

2. Configuration of customer apps, which connect with the so-called "supervisor" app on slave stations.

3. Test activation from the master station level.

4. Taking the test by ticking correct answers for successive questions (it is possible to add a clarifying figure to the questions - cf. fig. 8 - right).

5. Test completion (automatically after a set time elapses or manually - earlier).

6. Recording test results in a file (spreadsheet or text file, depending on the selected option, fig. 9) 


\section{Conclusions}

The elaboration presents applications, that enable the improvement of the reliability of an operator, developed in a graphical environment dedicated to processing visualisation. The term "operator", used in the listed summary phrases means "a given application user" and can be equivalent to, depending on the used application, a system designer, engineer or process operator. The advantages of using a SCADA package for this purpose are $[18,19]$ :

- utilising visualisation software for demonstrating, simulating and testing, used by an operator in the course of operating a SCADA system or DCS, which is a significant novelty of the approach;

- no need for special training of an operator in the scope of operating new software. The intuitive interface of all applications, similar to the normal operations of the operator;

- not using actual industrial equipment for educating and testing, hence, no need for online work;

- possibility, unless the, e.g., the testing process does not require locking such an option, to analyse the structure of the developed application and their use in practice;

- possibility for the operator to analyse window, application and conditional scripts utilised in the apps, which the logic of developed applications is based on;

- providing the operator with an option to learn the operation of dynamic graphical elements (check-boxes, radio buttons, drop-down menus, etc.).

\section{References}

1. Astor: Dokumentacja techniczna SaTerm 4 Software user guide Version 1.0, https://www.astor.com.pl/wsparcie/dokumentacja-techniczna/id/9043.

2. Astor: Radiomodem SATELLAR - integracja radiowej sieci Ethernet i szeregowej w jednym systemie Sattellar, http://www.elektroonline.pl/p/2900,Radiomodem-SATELLAR-integracja-radiowej-sieci-Ethernet-i-szeregowej-w-jednym-systemie.

3. Bednarek M.: Wizualizacja procesów. Laboratorium, Oficyna Wydawnicza Politechniki Rzeszowskiej, Rzeszów 2004.

4. Będkowski L., Dąbrowski T.: Podstawy eksploatacji, cz. 2. Podstawy niezawodności eksploatacyjnej. Wyd. WAT, Warszawa 2006.

5. Będkowski A., Będkowski L.: Proces egzaminowania jako proces diagnozowania stanu. Neodidagmata VII, UAM, Poznań 1975.

6. Będkowski L., Dąbrowski T.: Diagnozowanie operatora w systemie antropotechnicznym. III Krajowa Konferencja DIAG'95 „Diagnostyka Techniczna Urządzeń i Systemów”, Szczyrk. Wyd. ITWL, t. 4, 1995. 
7. Colbert E.J.M., Kott A. (eds.): Cyber-security of SCADA and Other Industrial Control Systems. Advances in Information Security, Vol. 63, Springer International Publishing, Switzerland.

8. Dąbrowski T.: Diagnozowanie systemów antropotechnicznych w ujęciu potencjałowoefektowym. Wyd. WAT, Warszawa 2001.

9. https://moodle.org/

10. https://new.abb.com/

11. http://platforma.astor.com.pl/

12. https://www.satel.com/products/radio-modems/netco/

13. https://www.youtube.com/channel/UCv7fy7uUd02Qli8XdsoLNuw

14. Instalacja oprogramowania Platforma Systemowa Wonderware 2017 UPDATE 3, Informator Techniczny Wonderware nr 171, 18-03-2019, www.astor.com.pl/wsparcie/dokumentacja-techniczna/pobierz/1075783

15. MODBUS over Serial Line Specification and Implementation Guide, Modbus.org, 2005, www.modbus.org/docs/Modbus_over_serial_line_V1_02.pdf.

16. Nugraha E., Abdullah A.G., Hakim D.L.: Designing a SCADA system simulator for fast breeder reactor. IOP Conference Series: Materials Science and Engineering, Vol. 128, International Conference on Innovation in Engineering and Vocational Education, 14 November 2015, Bandung, Indonesia.

17. Obradovic J., Milovanovic M., Despotovic-Zrakic M., Lukic J., Stokic A.: A using BPMN and Intouch HMI software for modeling of sampling system in refineries. Metalurgia International, Vol. 17, Iss. 11, 2012.

18. Patil C., Sonawane H., Patil K.: Overview of SCADA Application in Thermal. Proceedings of International Conference on Modeling and Simulation in Engineering \& Technology (Icmset-2014), 2014.

19. Wijaksono U., Abdullah A. G., Hakim D.L.: Design of virtual SCADA simulation system for pressurized water reactor. AIP Conference Proceedings 1708, 050005, 2016. 


\section{WYBRANE NARZĘDZIA ZWIĘKSZAJĄCE NIEZAWODNOŚĆ CZLOWIEKA W SYSTEMIE ANTROPOTECHNICZNYM}

\section{Wprowadzenie}

Rozproszone systemy sterowania (DCS - ang. Distributed Control System, rys. 1) składają się ze stacji procesowych, stacji operatorskich, stacji inżynierskich oraz pozostałych elementów pozwalających na wymianę danych pomiędzy systemami przemysłowymi $[3,12]$. Stacje procesowe są sterownikami przemysłowymi prowadzącymi sterowanie procesami, stacje operatorskie służą do wizualizacji i oddziaływań operatorskich, stacje inżynierskie przeznaczone są do konfiguracji, programowania i uruchamiania programów sterowania oraz wizualizacji. Elementy systemu DCS połączone są za pomocą sieci przemysłowej.

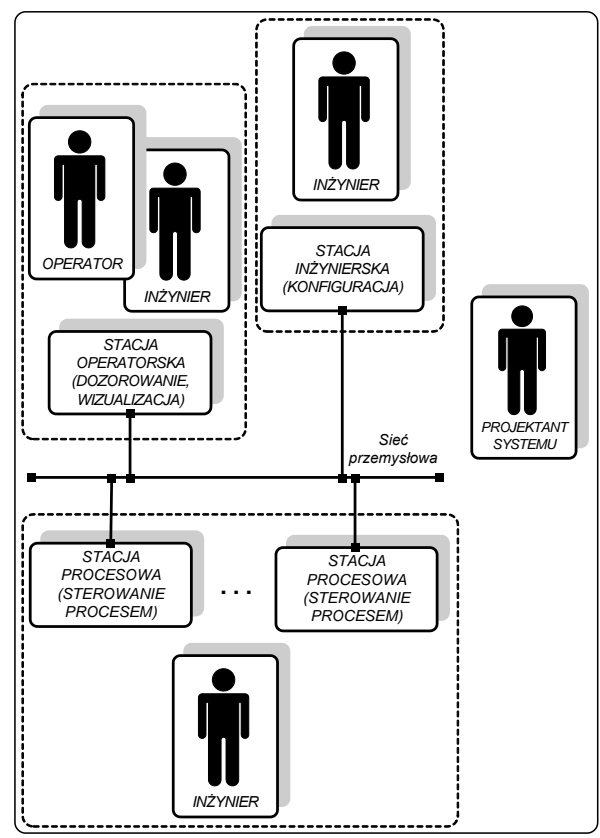

Rys. 1. Schemat rozpatrywanego rozproszonego systemu sterowania 
Wspomniany system można traktować jako system antropotechniczny (ewentualnie jako socjotechniczny) [8]. Czynnik ludzki ma wpływ na każdy z istotnych etapów istnienia systemu. Można wskazać różne role człowieka (rys. 1):

- projektant systemu - niezawodne funkcjonowanie systemu, dobór elementów sprzętowych, konfiguracja przesyłu danych pomiędzy stacjami sieci przemysłowej,

- inżynier - uruchomienie systemu, konfiguracja programowa stacji procesowych, konfiguracja stacji operatorskich - obrazy synoptyczne, wirtualne stacyjki urządzeń (z poziomu stacji inżynierskiej),

- operator - obserwacja wizualizacji, właściwa obsługa operatorska systemu (z poziomu stacji operatorskiej).

Niezawodność takiego systemu zależy od niezawodności części technicznej (sprzętowej i programowej), ale także od niezawodności działań projektanta, inżyniera oraz operatora.

Na niezawodność człowieka duży wpływ ma poziom jego wiedzy oraz predyspozycje psychomotoryczne [4-6,8]. Zwiększenie niezawodności projektanta/inżyniera/operatora można osiągnąć m.in. poprzez odpowiednie uczenie oraz weryfikację wiadomości (wiedzy). Na rys. 2 przedstawiono schematycznie ilustrację wpływu użycia narzędzi wspomagających właściwości niezawodnościowe systemu, poprzez zwiększanie niezawodności człowieka w systemie antropotechnicznym. Narzędzia opisane w dalszej części opracowania mają wpływ na większość elementów systemu.

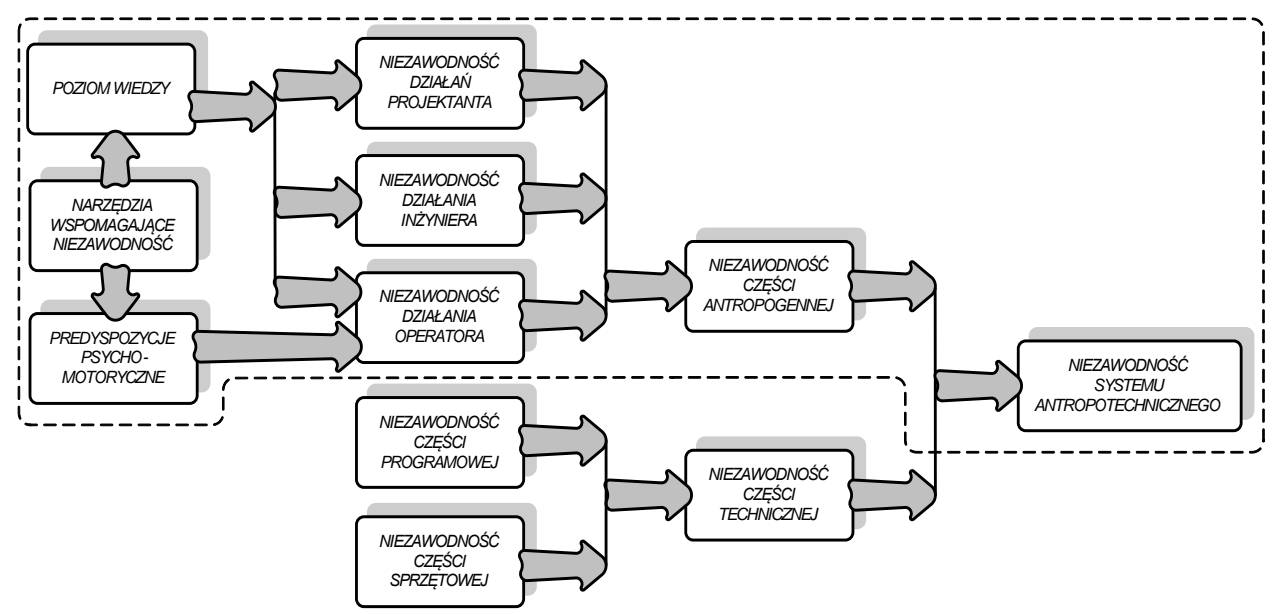

Rys. 2. Ilustracja wpływu narzędzi wspomagających właściwości niezawodnościowe systemu antropotechnicznego 


\section{Rola i miejsce narzędzi wspomagających niezawodność czlowieka}

Istnieje wiele sposobów pozyskiwania wiedzy technicznej. Projektant, inżynier i operator rozproszonego systemu sterowania w celu podwyższenia poziomu wiedzy mogą skorzystać m.in. z:

- dokumentacji technicznej zawartej w statycznych plikach tekstowych, będącej odpowiednikiem papierowej, drukowanej dokumentacji techniczno-ruchowej lub informatorów technicznych wydawanych przez producentów i integratorów sprzętu [14];

- interaktywnej pomocy (ang. help) zawartej bezpośrednio w używanym systemie informatycznym, często wzbogacanym o menu kontekstowe ułatwiające wyszukiwanie żądanych zagadnień [16];

- dokumentacji technicznej, zawierającej osadzone w tekście pliki multimedialne pozwalające, po zapoznaniu się z częścią teoretyczną opracowania, odtworzyć film instruktażowy - tego typu dokumentacja wykorzystywana jest w celach podniesienia wiedzy operatora przeprowadzającego obsługę systemu;

- portalu internetowego wspierającego produkty, gdzie można znaleźć tematycznie i chronologicznie ułożone materiały edukacyjne [15];

- internetowej platformy firmowej udostępnianej klientom, po zalogowaniu zawierającej oprócz standardowych elementów instalacyjnych systemu, bardzo często dodatkowe dokumenty [14];

- prezentacji multimedialnych dostępnych z poziomu subskrybowanego kanału internetowego serwisu, umożliwiającego wymianę filmów [13].

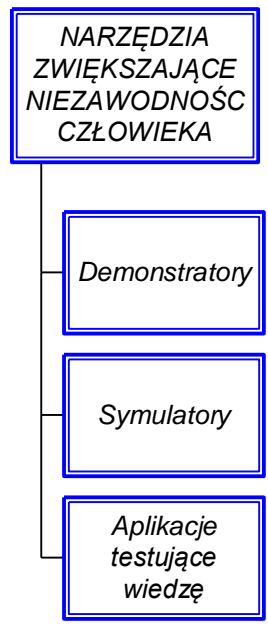

Rys. 3. Kategorie opracowanych narzędzi zwiększających niezawodność człowieka 
Zwiększenie niezawodności czynnika antropogennego w rozproszonym systemie sterowania (traktowanym jako system antropotechniczny), może nastąpić poprzez wykorzystanie przedstawionych w artykule wspomagających narzędzi informatycznych. Rysunek 3 przedstawia kategorie narzędzi, do których można zaliczyć opracowane oprogramowanie (rys. 4):

- interaktywne demonstratory komputerowe, umożliwiające zarówno poznanie działania pewnych mechanizmów, jak i wykonanie samodzielnego przykładu na danych użytkownika (por. demonstrator obliczania sum kontrolnych - punkt 3 artykułu);

- symulatory, pozwalające na skonfigurowanie pewnego fragmentu systemu lub np. połączenia oraz przetestowania umiejętności praktycznych operatora [11] (por. symulator systemu konsoli radiomodemów przemysłowych - punkt 4);

- aplikacje testujące wiedzę (często w postaci „quizu”), które służą do sprawdzenia wiedzy użytkownika; realizowane w postaci samodzielnych aplikacji, czy też z wykorzystaniem systemów e-learningowych [14] (por. aplikacja do testowania wiedzy operatora - punkt 5 artykułu).

Przedstawione dalej aplikacje zwiększające niezawodność człowieka w systemie antropotechnicznym, tj.:

- demonstrator obliczania sum kontrolnych,

- symulator konsoli radiomodemów przemysłowych,

- aplikacja do testowania wiedzy operatora,

wykonane zostały w pakiecie wizualizacyjnym [12]. Jest to istotny aspekt nowości. Wykorzystanie pakietu SCADA (ang. Supervisory Control and Data Acquisition) Intouch, z którym pracuje zarówno projektant, inżynier, jak i operator, daje dodatkowe możliwości praktycznego przećwiczenia jego obsługi. Nie ma konieczności dodatkowego wprowadzania użytkowników w ,,arkana” obsługi obcych aplikacji.

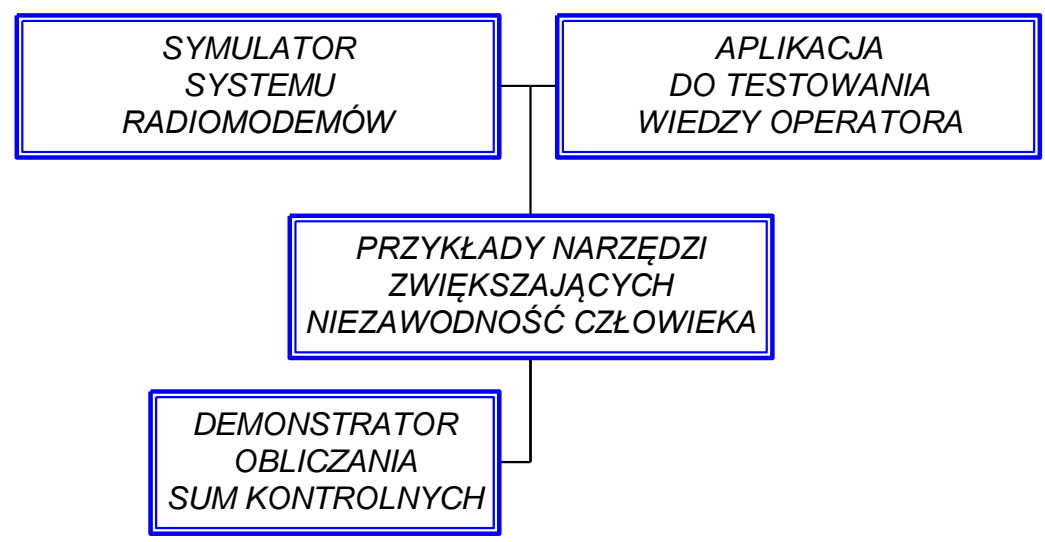

Rys. 4. Przykłady narzędzi wspomagających niezawodność człowieka 


\section{Demonstrator obliczania sum kontrolnych}

Aplikacja pozwala wszystkim grupom użytkowników na przeanalizowanie zasady obliczania cyklicznej sumy kontrolnej CRC16 [18].

Obliczenia sumy kontrolnej wykorzystywane są m.in. w procesie transmisji danych w rozproszonych systemach sterowania do sprawdzenia integralności przesyłanego komunikatu. Porównanie wartości sumy kontrolnej obliczonej na podstawie danych znaczących odebranego komunikatu $\mathrm{z}$ wartością dołączoną do niego jest kluczową czynnością przed podjęciem ewentualnej próby retransmisji. Stosowanie zabezpieczenia integralności przesyłu jest niezbędne we wszystkich systemach sterowania. Aplikacja opracowanego demonstratora pozwala na:

- wizualizację automatyczną zasady procesu obliczania sumy kontrolnej. Demonstrator odtwarza samodzielnie sekwencyjnie kolejne kroki obliczeń. $\mathrm{Na}$ ekranie pojawiają się kolejne etapy procesu obliczania, poprzez wyróżnienie innym kolorem ramki bloku algorytmu przedstawionego na ekranie synoptycznym (rys. 5);

- wizualizację automatyczną przykładu obliczania sumy kontrolnej. Podobnie do wizualizacji automatycznej zasady procesu, odbywa się to automatycznie. Uzupełnieniem są wyskakujące okienka zawierające wartości cząstkowe i końcową wartość rejestru sumy kontrolnej;

- obserwację „krok po kroku” zasady obliczeń każdego z etapów uzyskania wartości sumy kontrolnej, inicjowaną przez operatora. Dodatkowo istnieje możliwość uzyskania informacji uzupełniających po kliknięciu w blok wizualizowanego algorytmu;

- wykorzystanie jako quasi-kalkulatora do obliczeń sumy kontrolnej dla zadanego ciągu znaków (wprowadzoną wartością 16 bitowego słowa użytkownika). 


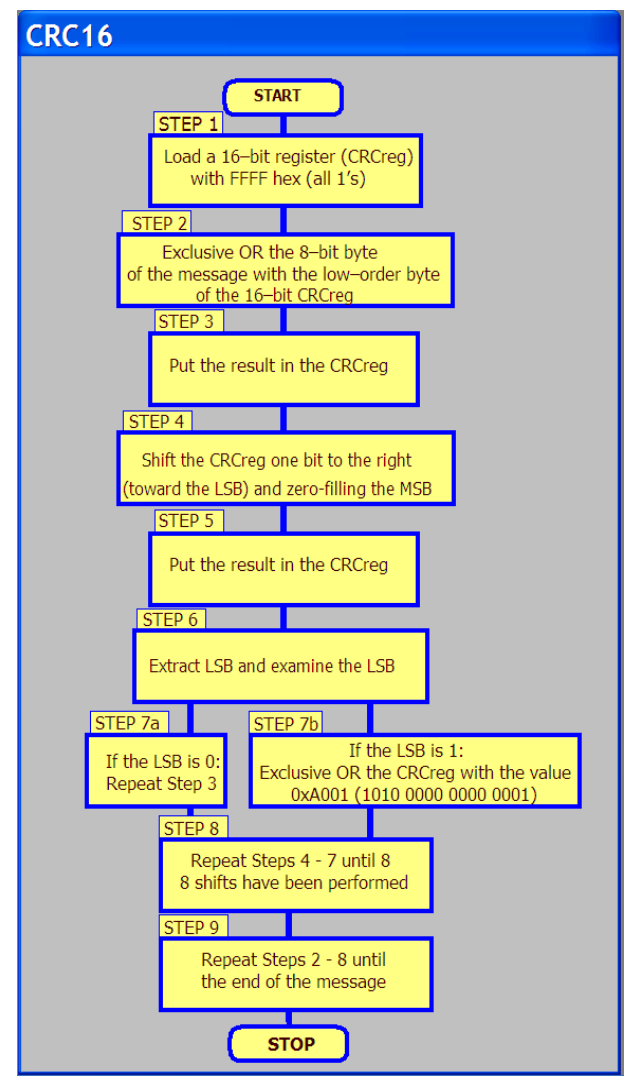

Rys. 5. Demonstrator obliczania sumy kontrolnej CRC-16

\section{Symulator konsoli radiomodemów przemyslowych}

Rzeczywiste radiomodemy przemysłowe $[2,7]$ pozwalają zestawić połączenie radiowe pomiędzy elementami rozproszonego systemu sterowania. Po odpowiednim skonfigurowaniu rzeczywistych urządzeń uzyskuje się linię przesyłową danych, praktycznie „niewidoczną” dla komunikujących się wzajemnie urządzeń. Istnieją wprawdzie graficzne konfiguratory modemów [1, 12], ale nie mają one jednak funkcji autonomicznej symulacji zestawionego kanału transmisyjnego, umożliwiającego uzyskanie efektu zestawienia połączenia bez użycia rzeczywistego sprzętu. Można dzięki nim skonfigurować rzeczywisty system radiomodemów i przesłać konfigurację do urządzeń.

Dzięki zastosowaniu aplikacji symulatora konsoli radiomodemów wykonanego w pakiecie wizualizacji użytkownik otrzymuje możliwość zestawienia symulowanego połączenia radiowego bez konieczności angażowania hardware’u. W tym celu należy dokonać: 
1. Konfiguracji wstępnej, polegającej na zaznaczeniu za pomocą odpowiednich pól wyboru możliwości wzajemnego komunikowania się poszczególnych modemów (rys. 6). Zaznaczenie check box-a powoduje konieczność skonfigurowania w kolejnym kroku wszystkich modemów biorących udział w symulowanej komunikacji (zaznaczonych).

2. Konfiguracji parametrów transmisyjnych każdego symulowanego modemu (częstotliwości, kanału transmisji, adresu dla danych wychodzących oraz przychodzących i pozostałych ustawień). Czynności te przeprowadza się kilkoma dostępnymi sposobami, analogicznie do rzeczywistego systemu, czyli za pomocą symulowanego okna pracy terminalowej - szeregu pytań i odpowiedzi lub poprzez wykorzystanie wirtualnych przycisków „góra”, „,dół”, ,,anuluj”, ,potwierdź” i alfa-numerycznego wyświetlacza podobnego do rzeczywistego wyświetlacza znajdu-jącego się na obudowie radiomodemu, wyświetlającego komunikaty.

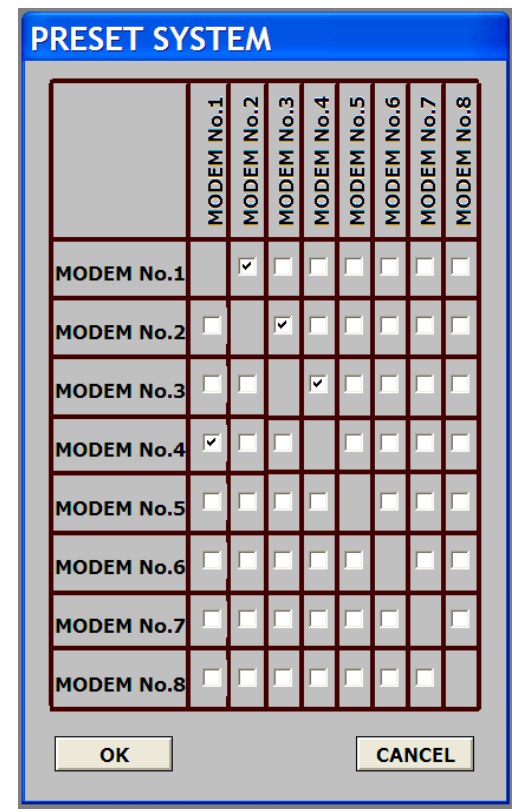

Rys. 6. Symulator zespołu radiomodemów przemysłowych - konfiguracja wstępna

3. Przełączenia (klikając na odpowiedni przycisk) na widok zestawionego połączenia (rys. 7). W przypadku prawidłowego skonfigurowania szeregu modemów pojawią się linie ze strzałkami, pokazujące kierunek i zwrot przesyłanych danych.

Połączenie zestawione $\mathrm{w}$ ten sposób umożliwia użytkownikowi otwarcie okna symulowanego terminala i przetestowanie komunikacji poprzez wpisanie w okienku tekstowym przyporządkowanym do skrajnego modemu nadawczego dowolnych znaków z klawiatury oraz obserwację pojawiających się znaków w oknie terminala modemu odbiorczego po drugiej stronie zestawionego połączenia. Właściwa konfiguracja łańcucha 
modemów umożliwia także uzyskanie połączenia symulatora systemu konsoli radiomodemów poprzez emulowane porty szeregowe z zewnętrznymi aplikacjami podrzędnymi działającymi wg protokołu Modbus.

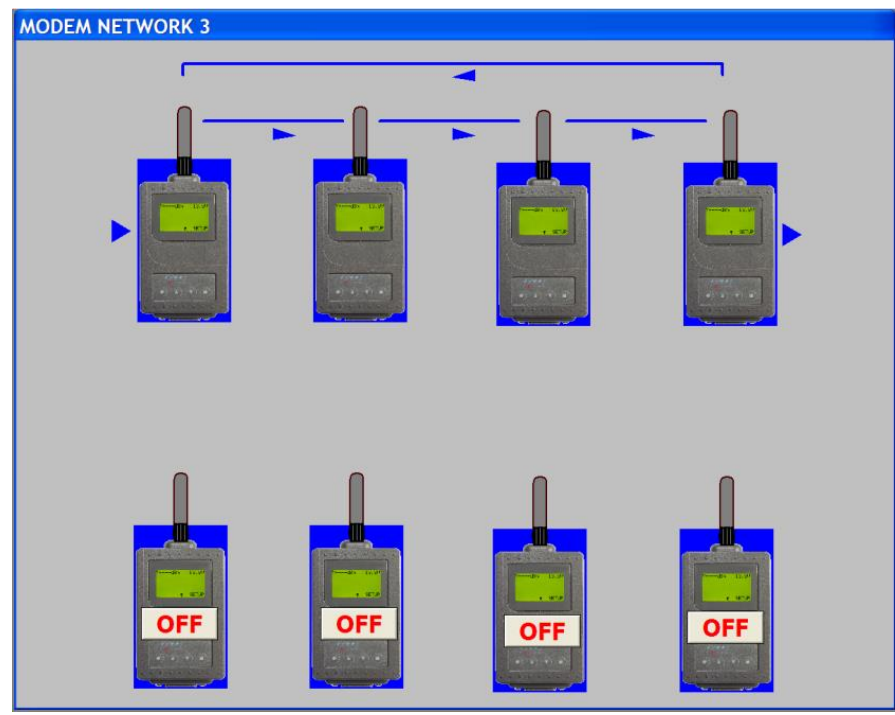

Rys. 7. Symulator zespołu radiomodemów przemysłowych - uruchomiony układ

\section{Aplikacja do testowania wiedzy operatora}

Ostatnim spośród narzędzi wymienionych w punkcie 2, zwiększających niezawodność człowieka w rozpatrywanym systemie antropotechnicznym, jest aplikacja testująca wiedzę operatora [5]. Należy podkreślić, że jest ona zrealizowana w środowisku graficznym pakietu SCADA, wykorzystywanym przez operatora w codziennej pracy. Możliwe jest jedno- lub wielostanowiskowe działanie aplikacji.

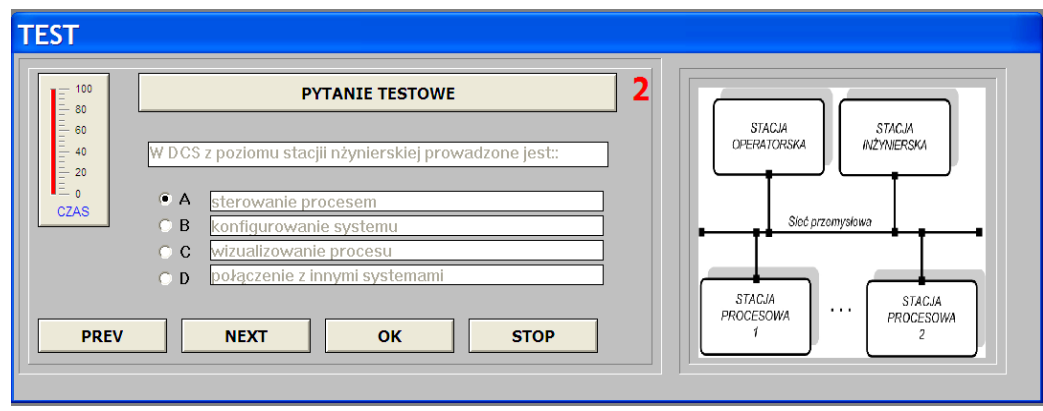

Rys. 8. Aplikacja testująca wiedzę operatora - okno quizu 


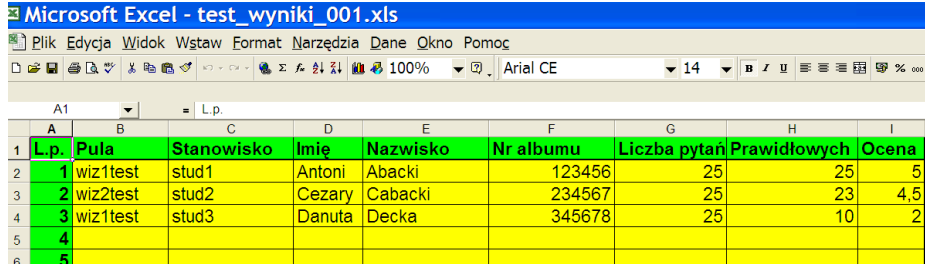

Rys. 9. Aplikacja testująca wiedzę operatora - wyniki

Sposób korzystania z aplikacji jest następujący:

1. Wstępna konfiguracja aplikacji obejmująca ustawienie przez nadrzędną stację m.in.: liczby stacji uczestniczących w teście, danych i identyfikatorów użytkowników, liczby pytań w teście, czasu aktywności, miejsca źródłowego i pliku z pytaniami.

2. Konfiguracja aplikacji klienckich, łączących się z aplikacją tzw. trenerską na stacjach podrzędnych.

3. Uruchomienie testu $\mathrm{z}$ poziomu stacji nadrzędnej.

4. Realizacja testu poprzez zaznaczanie odpowiednich odpowiedzi dla kolejnych pytań (do pytań możliwe jest dodanie rysunku wyjaśniającego - rys. 8 po prawej).

5. Zakończenie testu (automatyczne po upływie zadanego czasu lub ręczne - wcześniejsze).

6. Zapisanie wyników testu do pliku (arkusza kalkulacyjnego lub tekstowego w zależności od wybranej opcji, rys. 9).

\section{Podsumowanie}

W opracowaniu przedstawiono aplikacje umożliwiające zwiększenie niezawodności operatora wykonane $\mathrm{w}$ graficznym środowisku przeznaczonym do wizualizacji procesów. Termin „operator” użyty w wypunktowanych frazach podsumowania oznacza „korzystającego z danej aplikacji” i może być tożsamy, w zależności od użytej aplikacji z: projektantem systemu, inżynierem lub operatorem procesu. Korzyściami wynikającymi z użycia do tego celu pakietu SCADA są $[18,19]$ :

- wykorzystanie oprogramowania wizualizacyjnego do demonstracji, symulacji i testowania, którego operator używa podczas eksploatacji systemu SCADA lub rozproszonego systemu sterowania, co jest istotną nowością podejścia;

- brak konieczności specjalnego edukowania operatora w zakresie obsługi nowego oprogramowania; obsługa wszystkich aplikacji jest intuicyjna, nieodbiegająca od normalnej pracy operatora;

- nieangażowanie do edukacji i testowania rzeczywistego obiektu przemysłowego, a tym samym brak konieczności pracy online; 
- możliwość analizowania struktury wykonanych aplikacji i zastosowania w praktyce, o ile nie wymaga zablokowania takiej możliwości np. proces testowania;

- możliwość przeanalizowania przez operatora zastosowanych w aplikacjach skryptów okiennych, aplikacyjnych i warunkowych, na których opiera się logika wykonanych aplikacji;

- umożliwienie operatorowi nauki działania dynamicznych elementów graficznych (pól wyboru, przycisków radiowych, rozwijanych menu, itp.).

\section{Literatura}

1. Astor: Dokumentacja techniczna SaTerm 4 Software user guide Version 1.0, https://www.astor.com.pl/wsparcie/dokumentacja-techniczna/id/9043.

2. Astor: Radiomodem SATELLAR - integracja radiowej sieci Ethernet i szeregowej w jednym systemie Sattellar, http://www.elektroonline.pl/p/2900,Radiomodem-SATELLAR-integracja-radiowej-sieci-Ethernet-i-szeregowej-w-jednym-systemie.

3. Bednarek M.: Wizualizacja procesów. Laboratorium. Oficyna Wydawnicza Politechniki Rzeszowskiej, Rzeszów 2004.

4. Będkowski L., Dąbrowski T.: Podstawy eksploatacji, cz. 2. Podstawy niezawodności eksploatacyjnej, Wyd. WAT Warszawa 2006.

5. Będkowski A., Będkowski L.: Proces egzaminowania jako proces diagnozowania stanu. Neodidagmata VII. UAM, Poznań 1975.

6. Będkowski L., Dąbrowski T.: Diagnozowanie operatora w systemie antro-potechnicznym. III Krajowa Konferencja DIAG'95 „Diagnostyka Techniczna Urządzeń i Systemów”, Szczyrk. Wyd. ITWL, t. 4, 1995.

7. Colbert E.J.M., Kott A. (red.): Cyber-security of SCADA and Other Industrial Control Systems. Advances in Information Security, Vol. 63, Springer International Publishing Switzerland.

8. Dąbrowski T.: Diagnozowanie systemów antropotechnicznych w ujęciu potencjałowo-efektowym. Wyd. WAT, Warszawa 2001.

9. https://moodle.org/

10. https://new.abb.com/

11. http://platforma.astor.com.pl/

12. https://www.satel.com/products/radio-modems/netco/

13. https://www.youtube.com/channel/UCv7fy7uUd02Qli8XdsoLNuw

14. Instalacja oprogramowania Platforma Systemowa Wonderware 2017 UPDATE 3, Informator Techniczny Wonderware nr 171, 18-03-2019, www.astor.com.pl/ wsparcie/dokumentacja-techniczna/pobierz/1075783

15. MODBUS over Serial Line Specification and Implementation Guide, Modbus.org, 2005, www.modbus.org/docs/Modbus_over_serial_line_V1_02.pdf.

16. Nugraha E., Abdullah A.G., Hakim D.L.: Designing a SCADA system simulator for fast breeder reactor. IOP Conference Series: Materials Science and Engineering, Vol. 
128, International Conference on Innovation in Engineering and Vocational Education, 14 November 2015, Bandung, Indonesia.

17. Obradovic J., Milovanovic M., Despotovic-Zrakic M., Lukic J., Stokic A.: A using BPMN and Intouch HMI software for modeling of sampling system in refineries. Metalurgia International, Vol. 17, Iss. 11, 2012.

18. Patil C., Sonawane H., Patil K.: Overview of SCADA Application in Thermal. Proceedings of International Conference on Modeling and Simulation in Engineering \& Technology (Icmset-2014), 2014.

19. Wijaksono U., Abdullah A. G., Hakim D.L.: Design of virtual SCADA simulation system for pressurized water reactor. AIP Conference Proceedings 1708, 050005, 2016. 